\title{
Are close-following and breaching behaviours by basking sharks at aggregation sites related to courtship?
}

\author{
MAUVIS GORE ${ }^{1}$, LOTTE ABELS ${ }^{1}$, SHANE WASIK ${ }^{2}$, LUKE SADDLER ${ }^{2}$ AND RUPERT ORMOND ${ }^{1}$ \\ ${ }^{1}$ Marine Conservation International and Heriot-Watt University, Edinburgh, Scotland, ${ }^{2}$ Basking Shark Scotland, Oban, Scotland
}

\begin{abstract}
Basking sharks Cetorhinus maximus tend to aggregate in summer at favoured locations along Britain and Ireland's west coast. Sharks have been described approaching and close-following one another, often to one side. This has been interpreted as putative pre-mating behaviour. At aggregation sites around the Inner Hebrides we used boat-based observation and in-water and overhead drone video-photography to document behaviour and to determine the sex of individuals. It was confirmed that a shark will frequently move purposely towards another from a distance and swim to maintain a position either directly behind or closely to one side of a conspecific for short periods. Contrary to expectation, we found no relationship between the sex of a shark or its size and close-following. This suggests that following behaviours are not mainly related to courtship. Further, abrasions on the nose suspected to be related to male behaviour were found to occur on both sexes, although abrasions on pectoral fins, similarly suggestive of mating-related behaviour, were predominantly on females. Breaching by basking sharks has also been proposed as a means of attracting the opposite sex. We observed breaching by solitary sharks but commonly by sharks within aggregations, and at other times by more than one shark on the same day at the same time; but there was not any clear evidence to indicate that breaching is primarily related to mating. More likely individuals show close following chiefly for feeding-related hydrodynamic advantage. It remains plausible however that mature sharks make use of feeding aggregations to initiate pre-courtship behaviour.
\end{abstract}

Keywords: aggregation, courtship, feeding, foraging efficiency, breaching, maturity, Hebrides, West of Scotland, mating, drones

Submitted 21 October 2017; accepted 4 May 2018; first published online 21 June 2018

\section{INTRDDUCTION}

Basking sharks (Cetorhinus maximus), the second largest fish species, occur in temperate coastal seas in both northern and southern hemispheres, and in the Atlantic range as far north as northern Norway and the south-west coast of Iceland (Sims et al., 2015) and as far south as the Falkland Islands (Bigelow \& Schroeder, 1948). In the NE Atlantic they are primarily observed during mid- to late-summer surface feeding at sites along the west coasts of Britain and Ireland (Nicholson et al., 2000; Southall et al., 2005; Bloomfield \& Solandt, 2008; Speedie et al., 2009). Evidence suggests that most individuals make local seasonal movements (Sims, 2008) while some larger individuals also undertake transoceanic migrations (Gore et al., 2008; Skomal et al., 2009). In summer amongst the highest concentrations of surfacefeeding sharks occur around the islands of Coll, Gunna and Tiree in the Inner Hebrides, Scotland (Speedie et al., 2009; Gore et al., 2016), where on favourable days up to 200 individuals have been observed, and up to 800 individuals may occur over a 7-10 day period (Gore et al., 2016).

While normally in such areas most sightings are of solitary sharks, up to a quarter or more may be of sharks in loose aggregations of up to nine or more sharks feeding within a

Corresponding author:

M. Gore

Email: mauvis.gore.mci@gmail.com few hundred metres of each other (Gore et al., in prep.). The occurrence of such distinct groups was noted from the Minch off the Outer Hebrides Island of Barra as far back as 1947 by Matthews (1950) who suggested that social behaviour might be involved. Likewise Hallacher (1977) observed that in Carmel Bay, California, groups of two or three sharks were common, and described a group of 10 basking sharks (5$8 \mathrm{~m}$ in length) feeding in a straight line or circling before continuing ahead. Similarly, Harvey-Clark et al. (1999) described behaviour within an aggregation of 13 basking sharks (6-8 m length) during a $5 \mathrm{~min}$ aerial observation period off Nova Scotia, Canada. They observed groups of two or three individuals swimming in slow tight circles, nose-to-tail following, parallel swimming, and echelon swimming (with one individual to the side and behind another). They also described individuals making a flank approach, approaches leading to rostral contact with the tail, pectoral fin, vent or back, and also possible pectoral biting and nudging. They noted that some sharks had discrete white patches on their dorsum and fins, which they suggested could be related to mating behaviour. As with Wilson's (2004) observations, Harvey-Clark and colleagues concluded that the aggregation involved group reproductive activity rather than feeding behaviour.

Sims et al. (2000) also described possible social behaviour in basking sharks observed over 5 years between May and July during 25 separate events in coastal front areas in SW England. They described groups of two to four sharks participating in nose-to-tail following, echelon swimming and close 
flank approaches. They noted that while larger sharks of 5$8 \mathrm{~m}$ length were involved, those of $3-4 \mathrm{~m}$ were not, and that on three occasions they were able to identify the lead shark as female. They suggested that while the individual sharks may initially be attracted to aggregation areas to feed, it is feasible that they may then use the opportunity to find mates. The size at maturity for basking sharks is uncertain, but generally the females are thought to mature at a larger size $(\sim 7.24 \mathrm{~m}$ : Matthews, 1950$)$ than males $(>6.22 \mathrm{~m}$ : Matthews, 1950).

Sims et al. (2000) also recorded full breaches by basking shark taking place in the area where close-following was observed and suggested there may be a link. Breaching behaviour not related to fishing has been observed in several other shark species, including thresher (Alopias vulpinus), spinner (Carcharhinus brevipinna), blacktip (C. limbatus) and white shark (C. carcharias). A wide variety of functions for the behaviour have been proposed, including feeding, predator avoidance, mating, parasite removal and signalling (Curtis \& Macesic, 2011).

Despite the above observations and other detailed studies of basking sharks over 70 years, remarkably little is known of the species' reproductive cycle. Neither mating nor natural parturition has ever been observed, although one female has been reported to have delivered premature young after being harpooned by fishers in Norway (Sund, 1943), and a pregnant female was found to have 34 egg cases at the beginning of gestation (Ali et al., 2012). Published descriptions of mating in any shark species are scarce with most observations having been made in captivity. In a number of shark species biting of the female by the male leading to intromission was reported to result in scarring of the female in gill, pectoral fin and tail areas (Bres, 1993). In the wild mating has been observed in whitetip reef sharks (Triaenodon obesus) (Tricas \& Le Feuvre, 1985; Whitney et al., 2004) and silky shark (Clarke et al., 2013). Presumed courtship behaviours involving close-following and sometimes parallel swimming and fin-biting have been described in bonnethead sharks, Sphyrna tiburo (Myrberg \& Gruber, 1974), grey reef sharks, C. amblyrhynchos (Bres, 1993), nurse sharks, Ginglymostoma cirratum (Klimley, 1980; Pratt \& Carrier, 2001), blacktip reef sharks, C. melanopterus (Johnson \& Nelson, 1978) and lemon sharks, Negaprion brevirostris (Pratt \& Carrier, 2001).

While these comparisons support the interpretation that close-following and related behaviours in basking shark may be related to courtship, that this is the prime function has not been established. We took the opportunity of frequent encounters with basking sharks around the islands of Coll, Gunna and Tiree to investigate the hypotheses that (a) closefollowing and echelon swimming are a form of pre-courtship behaviour, (b) that abrasions on females are associated with males approaching females and (c) breaching by basking sharks is also related to courtship.

\section{MATERIALS AND METHDDS}

Observations described here were made between 22 June and 14 August 2016 in the waters around the islands of Coll, Gunna and Tiree in the Inner Hebrides off the west coast of Scotland (Figure 1). Coll and Tiree are both inhabited

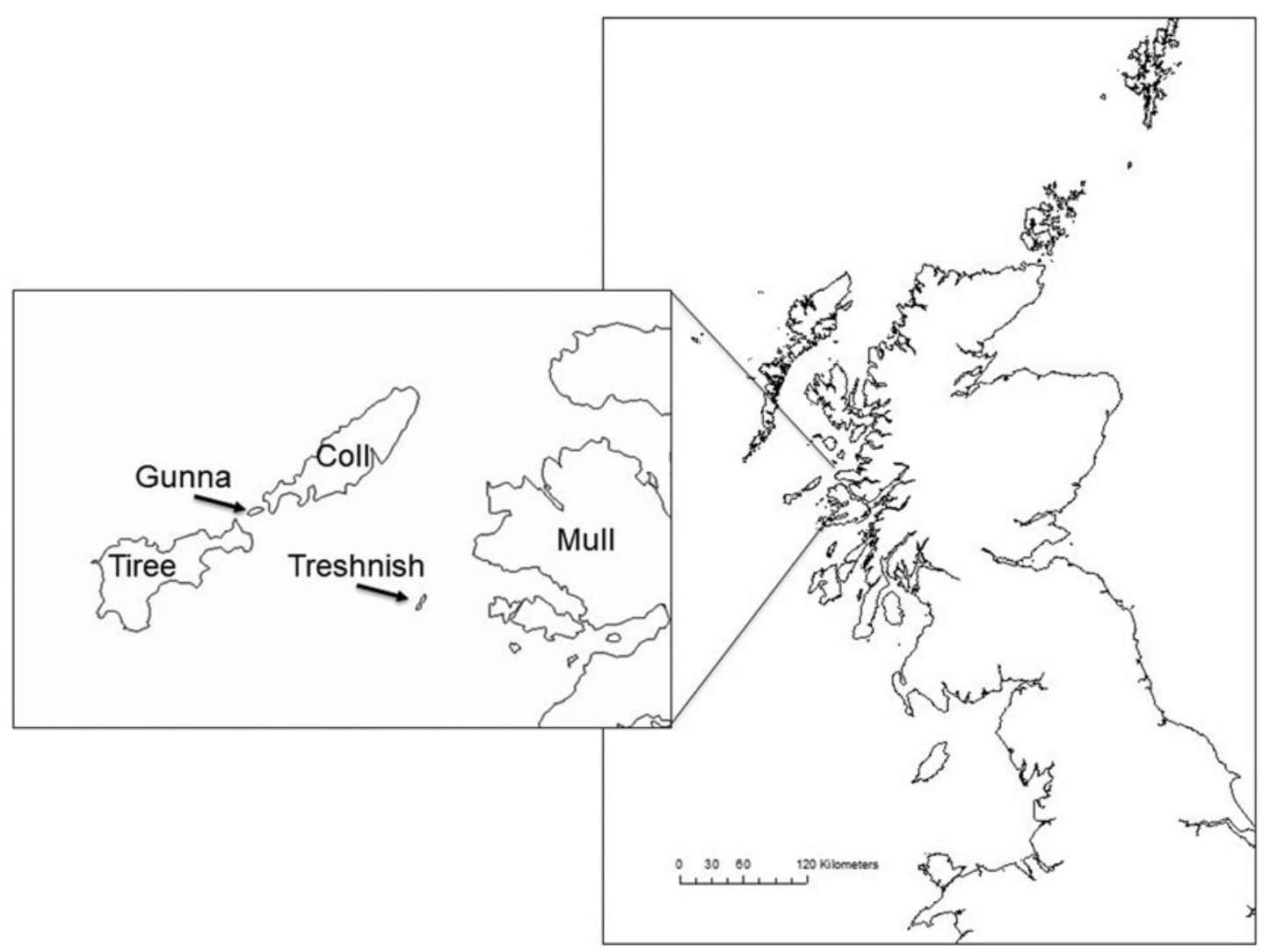

Fig. 1. Map of Scotland and western isles with inset of Inner Hebrides, showing the Isles of Coll, Gunna, Tiree, Treshnish and Mull (OS Open Data 2016). 
islands $\sim 20 \mathrm{~km}$ long and $2-8 \mathrm{~km}$ wide, with their long axes orientated north-east south-west. Gunna is a much smaller (1.75 km length) uninhabited island lying in the channel, Gunna Sound, that runs between the adjacent ends of the two larger islands. Strong tidal currents run through Gunna Sound and appear to result in surface concentrations of zooplankton on which the sharks feed. For recording purposes the study area has been divided into seven subareas (Figure 2), although during the main recording period survey work was confined to only five of these. Areas were primarily demarcated to reflect differences in coastal geomorphology and hence typical sea conditions and extent of use by basking sharks. Larger areas are ones where fewer observations were made per unit area, data from possible smaller sub-areas being combined so as to permit comparison of encounter rates per unit time.

Observations of basking sharks were made from a $9.8 \mathrm{~m}$ long RIB which, conditions permitting, made daily excursions to whichever areas, given prevailing weather, seemed most likely to reveal surface-feeding sharks. For each shark the total length was estimated and the following data recorded: location, date, time, sea surface temperature (SST, measured at $-0.5 \mathrm{~m}$ using a Raymarine Dragonfly sensor), sea state (using the World Meteorological Organisation sea state scale), wind speed, wind direction, cloud cover and state of the tide (UKHO, 2016, for Gott Bay, Isle of Tiree). Measurements given for basking sharks are total lengths estimated for nearby sharks in relation to markings on the boat and as double the linear distance between the tip of the first dorsal fin and the tip of the tail, when at a distance only these features were visible. When possible, a record was made of how many other sharks were present within a distance of $100 \mathrm{~m}$ and whether the focal shark appeared to be solitary or a member of a pair or larger group. Under most conditions other individuals surface feeding within $100 \mathrm{~m}$ were readily detectable by eye and usually would also be plotted beforehand or afterwards as the observation boat moved along the coast. Any instances where a basking shark was observed to be within $25 \mathrm{~m}$ of a conspecific(s) so that it could sense and initiate or react to the behaviour of another shark were designated as putative 'shark interaction'.

Weather and sea state (related to wave size) affect the ease with which the dorsal fin of surface-feeding basking sharks can be detected from a distance by boat-based observations. Above sea state 3 sharks cannot reliably be spotted at distances of more than $25 \mathrm{~m}$, whereas in sea state o sharks can be regularly spotted from 2 or $3 \mathrm{~km}$ away.

Seventy-nine hours of observation were completed within the 54 day study period. It should be noted however that because of the extended time spent observing many individual sharks, the overall encounter rate per unit time is considerably lower than it would have been had the survey boat been motoring forward throughout the survey periods. Survey work usually began in the two or three subareas most likely to yield sharks, with the survey route not being designed to obtain an overall estimate of shark density.

Three methods were used to observe and record the features and behaviour of a proportion of the sharks:

1. Above-water observations were made and recorded by a boat-based researcher who whenever practicable also noted the distinctive features of each individual shark so as to permit individual identification (see Gore et al., 2016). The behaviours shown by the sharks were recorded using a pre-defined set of categories, as characterized in Table 1.

2. Underwater observations were made by snorkellers who were either paying guests or the crew of the basking shark tour operator Basking Shark Scotland (BSS). Most snorkellers took underwater still or video images of the sharks with a variety of cameras. Many snorkellers made their imagery available to the research team when requested. BSS crew were asked if they could determine from observation whether each shark appeared to be male (with visible claspers) or female. It is possible however that some small immature sharks with no visible

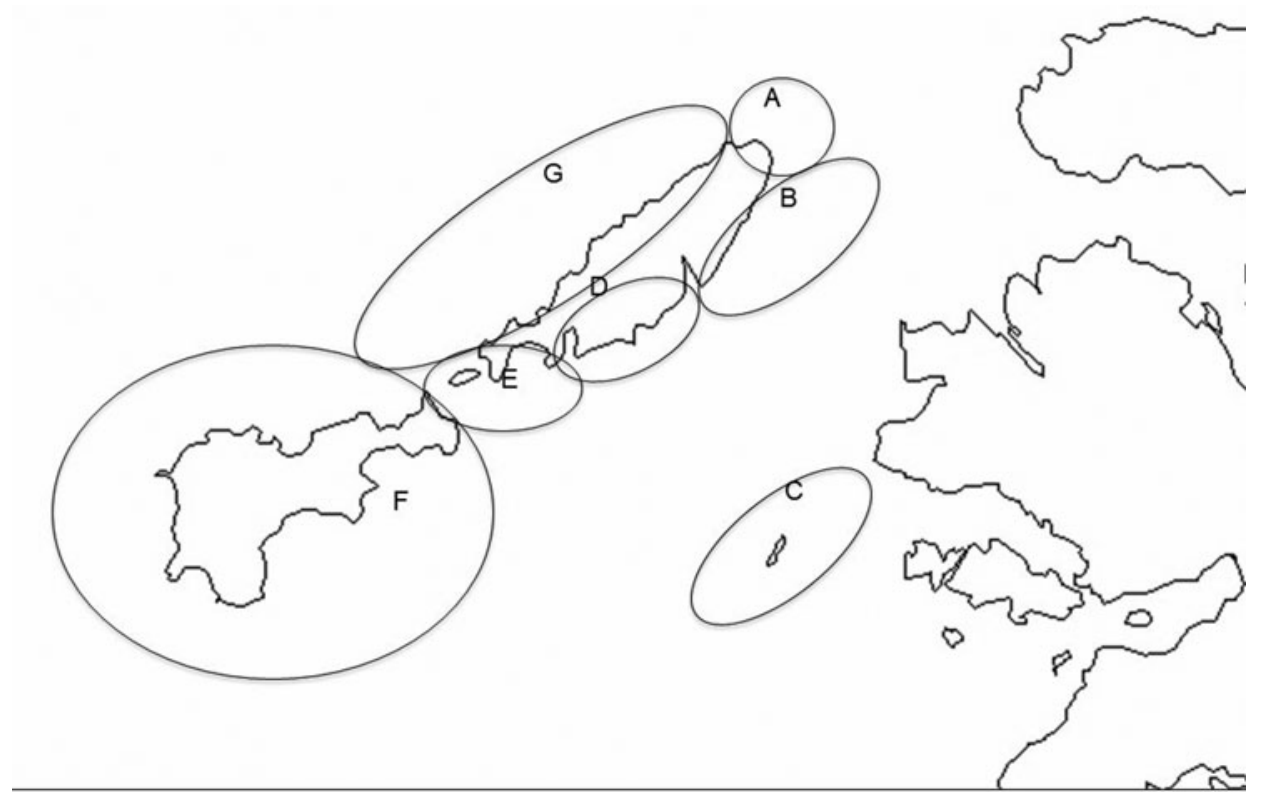

Fig. 2. Map of the Isles of Coll and Tiree with seven sub-areas distinguished in survey work. (A) Cairns of Coll; (B) North-East Coll; (C) Treshnish Isles; (D) South-East Coll; (E) Gunna Sound; (F) Tiree; (G) West Coll (OS Open Data 2016). 
Table 1. Description of behavioural categories used during the study. A body length was $\sim 5 \mathrm{~m}$.

\begin{tabular}{ll}
\hline Behaviour & \multicolumn{1}{c}{ Description } \\
\hline Cruising & $\begin{array}{c}\text { Shark is swimming forwards steadily, with the } \\
\text { mouth closed } \\
\text { Shark is feeding by swimming forwards with the } \\
\text { mouth wide open } \\
\text { One shark is following behind another within a } \\
\text { distance of no more than one body length }\end{array}$ \\
Close-following & $\begin{array}{c}\text { The nose of the following shark is at or close to the } \\
\text { tail or hind body of the leading shark }\end{array}$ \\
Nose-to-tail & $\begin{array}{c}\text { Two or more sharks swimming parallel and more or } \\
\text { less level with each other with not more than one } \\
\text { body length between them }\end{array}$ \\
Parallel swimming & $\begin{array}{c}\text { Sharks are stationed behind and to the side of the } \\
\text { shark in front less than a body length away } \\
\text { One or more sharks swimming below or below and } \\
\text { swightly behind another shark, a form of echelon } \\
\text { stacking }\end{array}$ \\
swimming & $\begin{array}{c}\text { Incorporates behaviours where a shark is within a } \\
\text { body length of another }\end{array}$ \\
Close-swimming & $\begin{array}{c}\text { Shark leaps partly or entirely out of the water before } \\
\text { falling back into the sea }\end{array}$ \\
Breaching &
\end{tabular}

claspers (NVC) were counted as female. Snorkellers were also asked to note the position on the body of fresh abrasions (skin patch colour from red to pink for recent occurrence or white when healing has begun). Snorkellers reported their observations to the boat-based researcher on return to the boat. Where possible photographs taken by crew and guests were also used to facilitate individual identification of the sharks.

3. Where practicable aerial video imagery of examples of close-following and similar behaviour were obtained by co-author LS using a Phantom 3 drone.

In all cases the boat, observer and snorkellers respected the responsible wildlife watching guide published by Scottish National Heritage (see http://www.snh.gov.uk/): boats did not normally approach sharks directly to within closer than $100 \mathrm{~m}$ and snorkellers in a group to within $4 \mathrm{~m}$, but both positioned themselves where it was anticipated a shark might approach them, which they frequently did, sometimes to within a distance of a metre or two. When using drones, in conformity with SNH's 2017 'A Guide to Best Practice for Watching Marine wildlife' advice that care should be taken not to disturb marine wildlife by flying too close to them, we avoided positioning a drone lower than $10 \mathrm{~m}$ above a swimming shark and more usually kept at more than twice this altitude. In no case was there any indication that the sharks even noticed the presence of the drone.

\section{RESULTS}

Table 2 shows the hours surveyed and the number of sharks encountered during the peak period (19 July-14 August 2016) within the main subareas. During this period a total of 322 sharks were encountered at a mean overall rate of 6.90 sharks $\mathrm{h}^{-1}$, the highest rates of sighting being in the west Coll $\left(9.27 \mathrm{~h}^{-1}\right)$ and Gunna Sound $\left(8.85 \mathrm{~h}^{-1}\right)$ subareas.
Table 2. The duration of basking shark surveys, the numbers of basking sharks sighted and the number of basking sharks encountered per hour (catch per unit effort, CPUE) during the peak observation period 19 July-14 August 2016 of the main subareas in the study.

\begin{tabular}{llcc}
\hline Area & Duration of survey & Number of sightings & CPUE \\
\hline Cairns of Coll & $1 \mathrm{~h} 5 \mathrm{~m}$ & 0 & 0.00 \\
NE Coll & $2 \mathrm{~h} 40 \mathrm{~m}$ & 1 & 0.38 \\
SE Coll & $7 \mathrm{~h} 3 \mathrm{~m}$ & 1 & 0.14 \\
Gunna sound & $29 \mathrm{~h} 15 \mathrm{~m}$ & 259 & 8.85 \\
W Coll & $6 \mathrm{~h} 35 \mathrm{~m}$ & 61 & 9.27 \\
Total & $46 \mathrm{~h} 38 \mathrm{~m}$ & 322 & 6.90 \\
\hline
\end{tabular}

On 234 occasions it was possible to determine the number of sharks visible within a $100 \mathrm{~m}$ radius of the focal shark. On over half of these occasions ( $54.7 \%)$ there were a total of $2-5$ sharks present within this distance, on $20.1 \%$ of occasions $6-9$ sharks and on $10.7 \%$ of occasions more than 10 sharks. On only $14.5 \%$ of occasions were solitary sharks the only individuals present within $100 \mathrm{~m}$ (Table 3 ).

The mean size of sharks whose lengths could be estimated during the focal period was $4.96 \mathrm{~m}( \pm 0.98 \mathrm{SD}$; range $3-7 \mathrm{~m}$, $\mathrm{N}=190$ ) (Figure 3A), with the result of a Shapiro-Wilk-test ( $W=0.9234, P=0.5521)$ suggesting that size range of sharks was normally distributed. The sex of the shark could be determined in 70 cases; 54 were female or immature, 16 were male. The mean size of confirmed male sharks $($ mean $=5.06 \pm$ $0.90 \mathrm{SD}$, range: $3-6 \mathrm{~m}$ ) was greater than that of female sharks (or possibly NVC sharks) (mean $=4.79 \pm 1.11 \mathrm{SD}$, range: $3-7 \mathrm{~m}$ ) (Figure $3 \mathrm{~B}$ ), but not the range of size.

During the study period the mean sea state was 3.6 (range 1-5), mean wind strength was Force 3.6 (range 1-7) with mean gust strength at 5.4 (range 3-9), while SST ranged from $13.4-15.0^{\circ} \mathrm{C}$. No strong trends in relation to basking shark aggregating behaviour were revealed on analysis, other than that the sightings rate was much reduced as sea-state increased. This finding may be solely due to the increasing difficulty of spotting shark fins amid larger waves or reflect in part reduced surface feeding when plankton swarms are dispersed by wave action. However, basking sharks were sometimes encountered surface feeding intensely amid waves as high as $1.5 \mathrm{~m}$.

\section{Shark interactions}

There were 48 occasions during the main study period when basking sharks were recorded interacting within $100 \mathrm{~m}$ of each other. Twenty-three of the 48 were observed from the boat, 18 by snorkelling and seven by drone. The sizes of the groups of sharks were a pair in 29 events, a trio in 11

Table 3. The number of focal basking sharks observed in groups of different sizes during the study overall.

\begin{tabular}{lc}
\hline Group size & Occasions \\
\hline 1 & 34 \\
$2-5$ & 128 \\
$6-10$ & 47 \\
$11+$ & 25 \\
Total & 234 \\
\hline
\end{tabular}



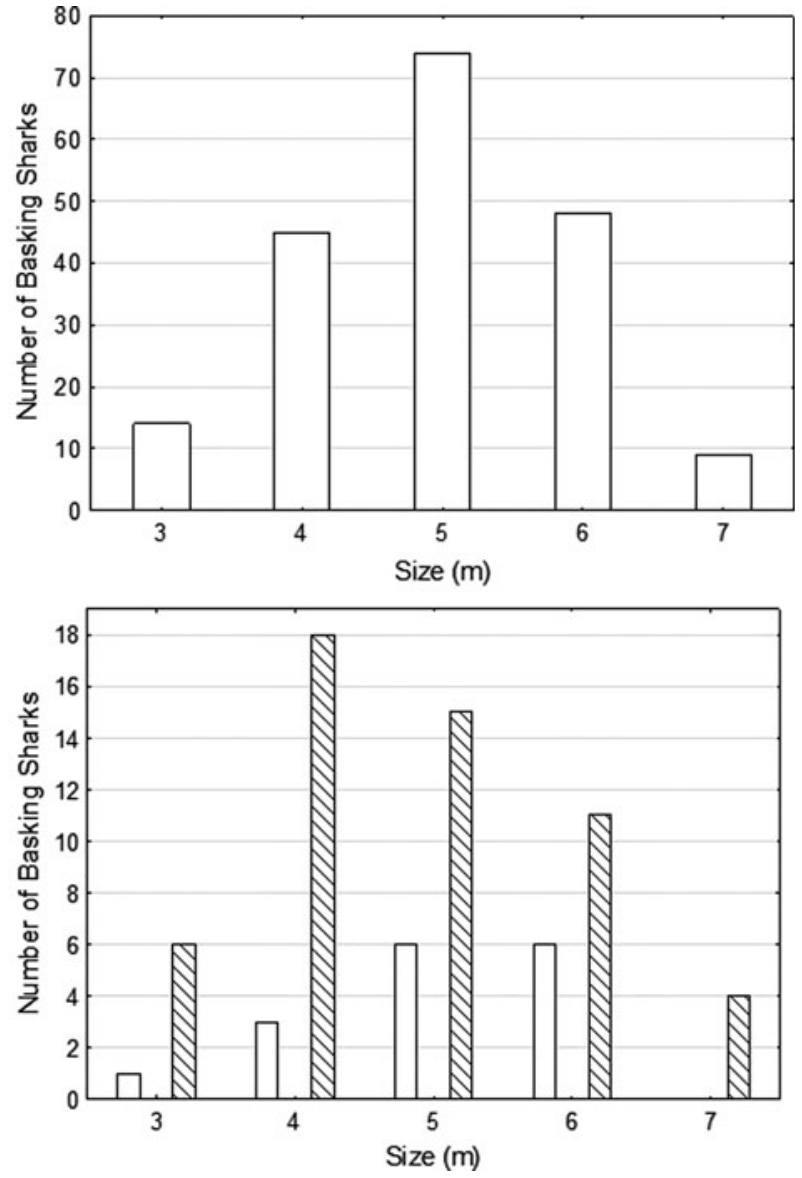

Fig. 3. The size distributions of basking sharks encountered during the main observation period of 19 July-14 August 2016, where size could be estimated, (Top) all sharks, (Bottom) males (empty bars) and females (or males with no visible claspers, NVC) (cross hatched bars).

events, four sharks feeding in four events, and one event each with five and with six sharks.

Basking sharks mostly fed independently (Figure 4) but were also on occasion approached directly by another shark, often as a prelude to close-following, as illustrated in the image (Figure 4) captured by drone. Various forms of closefollowing were observed on 41 occasions. Of these occasions, in 11 the lead shark was larger than the follower, in nine they were of equal size, and in 17 the lead shark was smaller than the follower, while in four cases the sizes could not be determined satisfactorily. An analysis of these data shows that

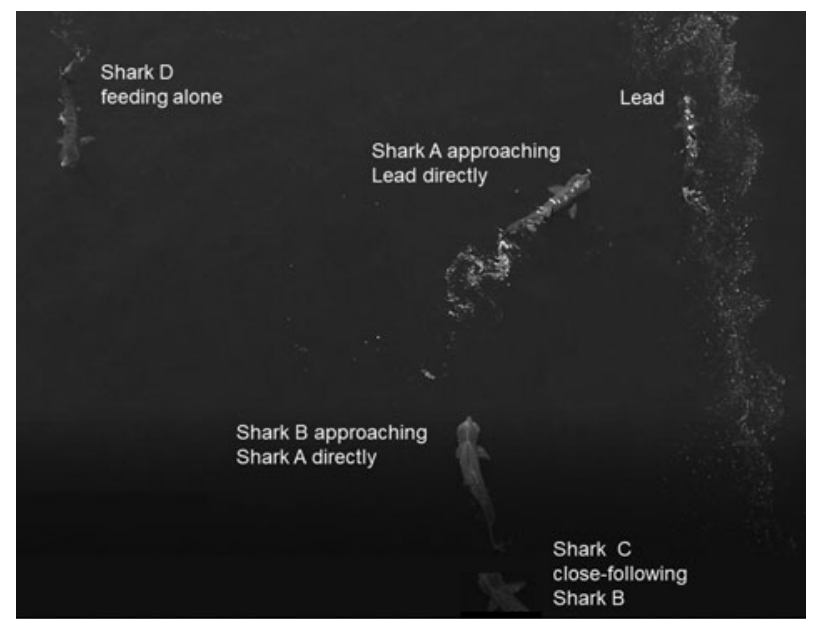

Fig. 4. Two examples of sharks approaching another directly captured by drone: Shark A approaching the lead shark and shark B approaching Shark A. Shark C is close-following shark B, while shark D is feeding alone.

there was overall no significant difference in the relative sizes of the lead and close-following shark $\left(\chi^{2}=2.81, \mathrm{df}=\right.$ 2, $P=0.3$ ).

Parallel swimming occurred in various group sizes, but tended to become echelon swimming, with one shark falling behind rather than remaining parallel (for example see Figure 5). In all 40 sharks were observed swimming in echelon. Two stacking events were recorded, one involving four female sharks and one of six sharks with five females and a male at the rear; in both events all the sharks were feeding. Cruising (that is, swimming without feeding) was observed both in solitary sharks and on occasions within groups.

The sustained distance of the following shark from the lead shark varied markedly from the follower being at the anal fin of, or nose-to-tail with, the leader, to the follower being up to two body lengths away (Table 4 ). There was a significant difference in the number of sharks following at different distances behind the leader $\left(\chi^{2}=27.4, \mathrm{df}=5, P<0.001\right)$, with the majority being $<0.5$ body length from the leading shark. The position of the following shark was to the left on 16 (72.7\%) occasions and to the right on five events. The additional video recordings (see Appendix $1(\mathrm{a}-\mathrm{f})$ ) revealed four occasions with the follower to the left and one with the follow to the right. The results show significantly more occasions where the following shark was on the left side of the lead shark $\left(\chi^{2}=7.5, \mathrm{df}=1, P<0.001\right)$.

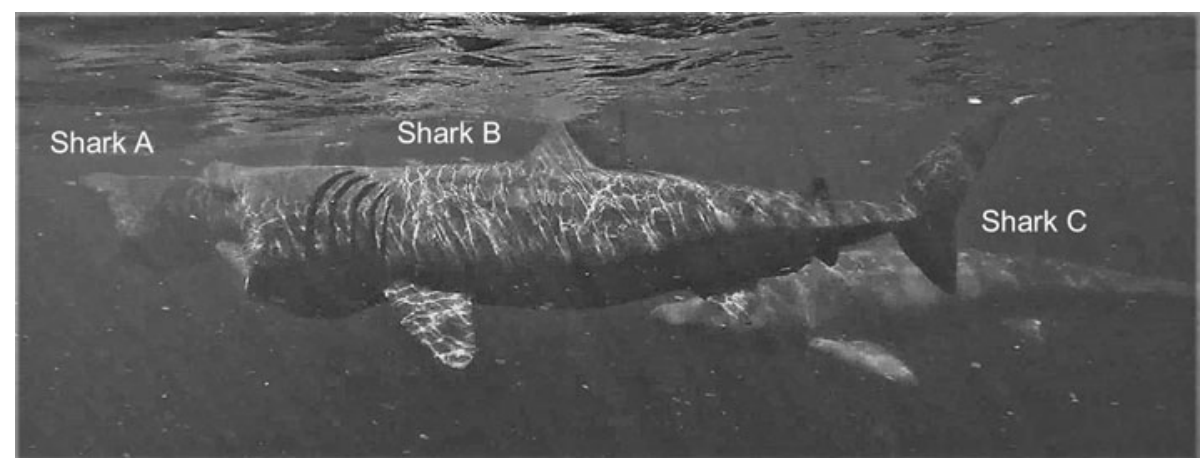

Fig. 5. Three basking sharks swimming in echelon, as seen underwater. 
Table 4. The distances between lead and follower sharks estimated as body lengths $(\sim 5 \mathrm{~m})$.

\begin{tabular}{lc}
\hline Distance of follower from leader (body-lengths) & Number of occasions \\
\hline o (nose to tail) & 4 \\
At anal fin & 9 \\
$\leq 0.5$ & 15 \\
$\leq 1$ & 16 \\
$\leq 1.5$ & 1 \\
$\leq 2$ & 2 \\
\hline
\end{tabular}

Where the sex of individuals could be determined during a close-following event (Table 5), a significant difference was found between the frequencies of different types of pairing $\left(\chi^{2}=8.8, \mathrm{df}=3, P=0.04\right)$. The most frequent occurrence $(66.7 \%)$ was that both sharks appeared to be female (or NVC). Only on one $(4.2 \%)$ of these occasions was a male $(5.5 \mathrm{~m})$ confirmed to be close-following a female $(4 \mathrm{~m})$ Inspection of additional underwater video material (Appendix 1(b)) provided seven occasions on which the sex of both the lead shark and one close-following behind could be determined (Table 5): on four occasions a male was recorded following a female, but on the other three occasions one female was observed to be following another. Together, the data show that males were following females (and possibly on occasion NVC sharks) in only $12.9 \%$ of the events.

When the sex and size of both sharks could be clearly determined and are taken together (Table 6), there was again a significant difference in the frequency of different types of pairing $\left(\chi^{2}=21.7, \mathrm{df}=9, \quad P=0.01\right)$. The predominant result was that females following a male were more often larger than the male, while in only one instance was a male $(5.5 \mathrm{~m})$ following a female $(4 \mathrm{~m})$.

\section{Abrasions on individuals}

During the study the natural markings and fin shape of 38 sharks were documented to allow individual identification (see Gore et al., 2016); of these sharks 23 were female (or NVC sharks) and 10 were male. Abrasions on pectoral fins of the type suspected of resulting from being held by a male seeking to mate were recorded on $43.5 \%$ of females (for example, see Figure 6) and $10.0 \%$ of males (Table 7). Abrasions on the nose, of the type suspected of being the result of a male pursuing and pushing at a female with his nose, were observed on $20.0 \%$ of males and $21.7 \%$ of females (Table 7). Most of the abrasions seen on the dorsum could be attributed to lampreys (for example, see Figure 7). Two males, 4 and $5 \mathrm{~m}$, had abrasions on their gill slits, a

Table 5. The sex of basking sharks observed participating in closefollowing events when the sex of both sharks could be determined. Note that Female may include small male sharks with no visible claspers.

\begin{tabular}{lccccc}
\hline Source of data & $\begin{array}{c}\text { Total } \\
\text { number } \\
\text { of events }\end{array}$ & $\begin{array}{c}\text { Male } \\
\text { follows } \\
\text { female }\end{array}$ & $\begin{array}{c}\text { Female } \\
\text { follows } \\
\text { male }\end{array}$ & $\begin{array}{c}\text { Female } \\
\text { follows } \\
\text { female }\end{array}$ & $\begin{array}{c}\text { Male } \\
\text { follows } \\
\text { male }\end{array}$ \\
\hline $\begin{array}{l}\text { Present study } \\
\text { Beecham, 2007 }\end{array}$ & 16 & 1 & 6 & 8 & 1 \\
$\quad 7$ & 4 & 0 & 3 & 0 \\
\hline
\end{tabular}

Table 6. Relationship between position, sex and size in close-following events, when both sex and size of both individuals could be estimated. '-' represents redundant category.

\begin{tabular}{llrr}
\hline Follower & & \multicolumn{2}{c}{ Leader } \\
\hline \multirow{3}{*}{ Female } & Size & Male & Female \\
& Larger & 6 & 2 \\
& Equal & 0 & 2 \\
Male & Smaller & 0 & 2 \\
& Larger & 0 & 1 \\
& Equal & 0 & - \\
\hline
\end{tabular}

location where scarring might be expected on females as a result of mating attempts by males.

\section{Breaching events}

Twenty-eight breaches were recorded during 15 events through the whole study period 22 June-14 August 2016, with the number of breaches per event ranging between one and five (Table 8). The number of sharks present within $100 \mathrm{~m}$ of a breaching individual varied between zero and 20 . Seven of the 15 events involved solitary individuals, one of which breached five times, while eight events occurred within $100 \mathrm{~m}$ of $1-20$ other sharks. Most breaches were performed by sharks with an estimated length of $5 \mathrm{~m}$, with $6 \mathrm{~m}$ being the largest estimated length and $3 \mathrm{~m}$ the smallest (Table 8). Conditions during breaching varied in respect to sea state (range $0-3$ ), SST (range $12.5-15.0^{\circ} \mathrm{C}$ ), weather (sunny, cloudy and rain) and time of day (09:32-17:49). However, breaching events (whether single or multiple) were recorded on only eight separate days through the survey period.

One breaching incident within an aggregation was recorded on a drone video (Figure 8; Appendix 1) and involved a $6 \mathrm{~m}$ lead shark and a $5 \mathrm{~m}$ (female) follower that maintained her position behind and to the left of the lead; both sharks swam directly forwards feeding for $3.5 \mathrm{~min}$. The lead shark then closed its mouth and accelerated while diving. It happened by then to be about 3 body lengths $(\sim 16 \mathrm{~m})$ from a group of waiting snorkel observers. After $7 \mathrm{~s}$, the pressure wave from the lead shark's dive footprint reached the nose of the follower, which then accelerated and also dived (but could still be seen clearly by the drone). The follower then breached, $14 \mathrm{~s}$ after it had submerged, while the lead shark then breached $13 \mathrm{~s}$ later. In Figure 9, the sequence of a basking shark breaching close to and away from a conspecific can be seen off the Cairns of Coll at

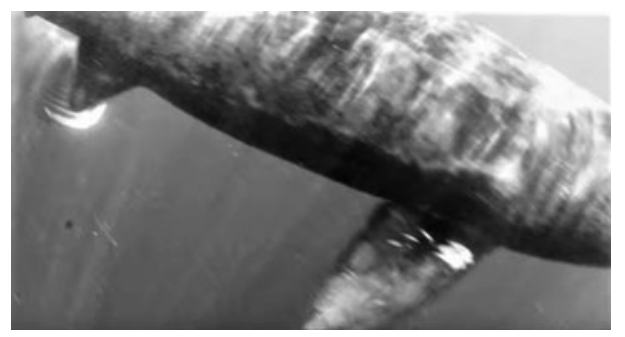

Fig. 6. The right pectoral fin of a female basking shark showing white abrasions. 
Table 7. The frequency of abrasions on one or both pectoral fins or the nose of individually identified male and female basking sharks.

\begin{tabular}{llll}
\hline Gender & $\begin{array}{c}\text { Number of } \\
\text { individuals }\end{array}$ & $\begin{array}{c}\text { Number with } \\
\text { abrasions on one/ } \\
\text { both pectoral fins }\end{array}$ & $\begin{array}{c}\text { Number with } \\
\text { abrasions on nose }\end{array}$ \\
\hline Female & 23 & 10 & 5 \\
Male & 10 & 1 & 2 \\
\hline
\end{tabular}

around 21:00 on 11 August 2015. The shark breached three times consecutively.

\section{DISCUSSIDN}

\section{Methodological issues}

During visual observation of basking sharks from above water aspects of their behaviour cannot be discerned with clarity and it is only occasionally that sharks can be sexed by an observer looking down through the water column. We therefore involved volunteer snorkellers to make underwater observations of the sharks and where possible obtain still or video imagery of them. We also used a radio-controlled aerial drone to record video imagery from overhead. While both close approach by boat and underwater observation during snorkelling might interfere with the basking sharks' natural behaviour, drones provided a method of precisely recording the behaviour and horizontal movements of surface swimming sharks with reduced risk of influencing their activity. A limitation was that the drone could only be deployed when weather conditions were suitable and the sharks present within range of a stable homing base. There may have been instances of sharks below the surface not seen using the boat or drone. Employing the three techniques in concert helped overcome the limitations of each single method.

Even with experienced snorkel observers it can be difficult to be certain whether a shark is male or female. Immature males have only very small claspers that typically do protrude from the anal fin area, and so may not be readily visible. Thus some small males may have been reported as female or NVC individuals. At the same time a significant proportion of

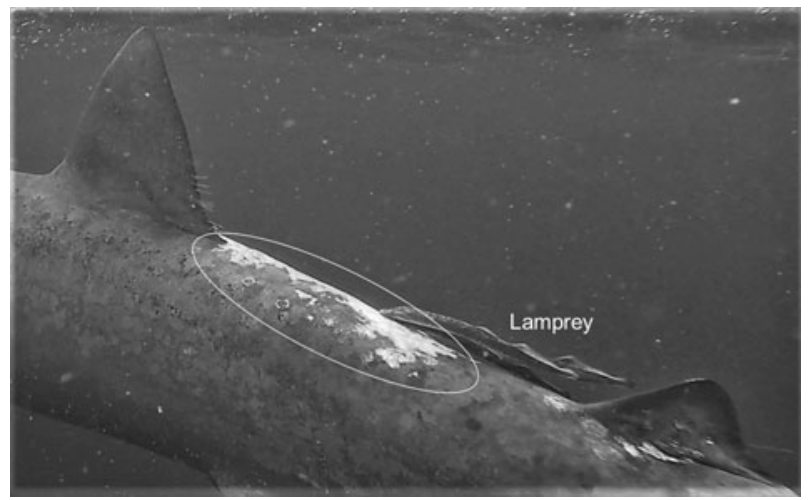

Fig. 7. A female basking shark (close-following a mature male out of image) with lamprey scars (inside white ring) on dorsum between dorsal fins. A live lamprey (Petromyzon marinus) is attached to her dorsum towards the rear of this area.
Table 8. Breaching events recorded between 22 June-14 August 2016.

\begin{tabular}{|c|c|c|c|c|}
\hline Date & Time & $\begin{array}{c}\text { Number } \\
\text { of breaches }\end{array}$ & $\begin{array}{l}\text { Shark total } \\
\text { length }(\mathrm{m})\end{array}$ & $\begin{array}{l}\text { Number of sharks } \\
\text { within } 100 \mathrm{~m}\end{array}$ \\
\hline 6/o6/2016 & $10: 50$ & 2 & $5 ; 5$ & 2 \\
\hline 19/07/2016 & $11: 20$ & 1 & 5 & 1 \\
\hline 19/07/2016 & $11: 40$ & 2 & $5 ; 5$ & 2 \\
\hline 19/07/2016 & $14: 18$ & 1 & & 1 \\
\hline $21 / 07 / 2016$ & $12: 02$ & 1 & & 1 \\
\hline 28/07/2016 & $12: 33$ & 1 & & 20 \\
\hline 28/07/2016 & $12: 50$ & 2 & & 20 \\
\hline 28/07/2016 & $13: 15$ & 1 & 6 & 20 \\
\hline 28/07/2016 & $14: 10$ & 1 & & 1 \\
\hline 29/07/2016 & $11: 22$ & 1 & & 1 \\
\hline $01 / 08 / 2016$ & $15: 24$ & 1 & & 1 \\
\hline $01 / 08 / 2016$ & $17: 49$ & 2 & $5 ; 6$ & 6 \\
\hline $02 / 08 / 2016$ & $09: 32$ & 2 & & 1 \\
\hline $14 / 08 / 2016$ & $11: 20$ & 5 & & 8 \\
\hline $14 / 08 / 2016$ & $11: 58$ & 5 & 3 & 4 \\
\hline
\end{tabular}

basking sharks (a third or more in this study area) carry lampreys, Petromyzon marinus, attached to their body. They are often attached to the base of dorsal or pectoral fins or the adjacent dorsum, or close to the area of the cloaca. In the latter location lampreys may be mistaken for claspers, hence conversely in a few cases individuals reported as male may actually have been female.

\section{Shark interactions}

While in many cases where basking sharks were close to one another there appeared to be no behavioural response by either shark, in other instances there clearly was a reaction. Bres (1993) noted that social behaviour in the form of dominance hierarchy based on size and sex has been observed in bull (C. leucas), bonnethead (S. tiburo), lemon (N. brevirostris) and Galapagos (C. galapogensis) sharks. Also, in their review, Jacoby et al. (2012) noted grouping behaviour in juvenile and adult sharks that could be distinguished as either aggregations or social groups. They suggested that social groups could be very short term and sporadic and may function for finding a partner and mating. In species that form schools, it has been proposed that population density may be needed to trigger mating behaviour (Demski, 1990).

\section{Are abrasions related to mating?}

We hypothesized, following Bres (1993) and Harvey-Clark et al. (1999), that the abrasions and scarring often noticeable on the dorsum, gills and pectoral fins of many individuals were injuries to the female caused by the attention of males looking to mate. The abrasions evident could be injuries to males caused by them repeatedly nudging and pushing against females prior to attempts at mating. We therefore expected abrasions in these areas to occur almost exclusively on females, and nose abrasions on males.

Abrasions on the dorsum of both sexes mostly appeared a result of recent lamprey attachment, and not a consequence of mating. Close inspection of images (for example, see Figure 7) show that the scars are mostly round in shape rather than elongated or unformed, and that they approximate to the size of lamprey mouths. Older lamprey scars appear as black 

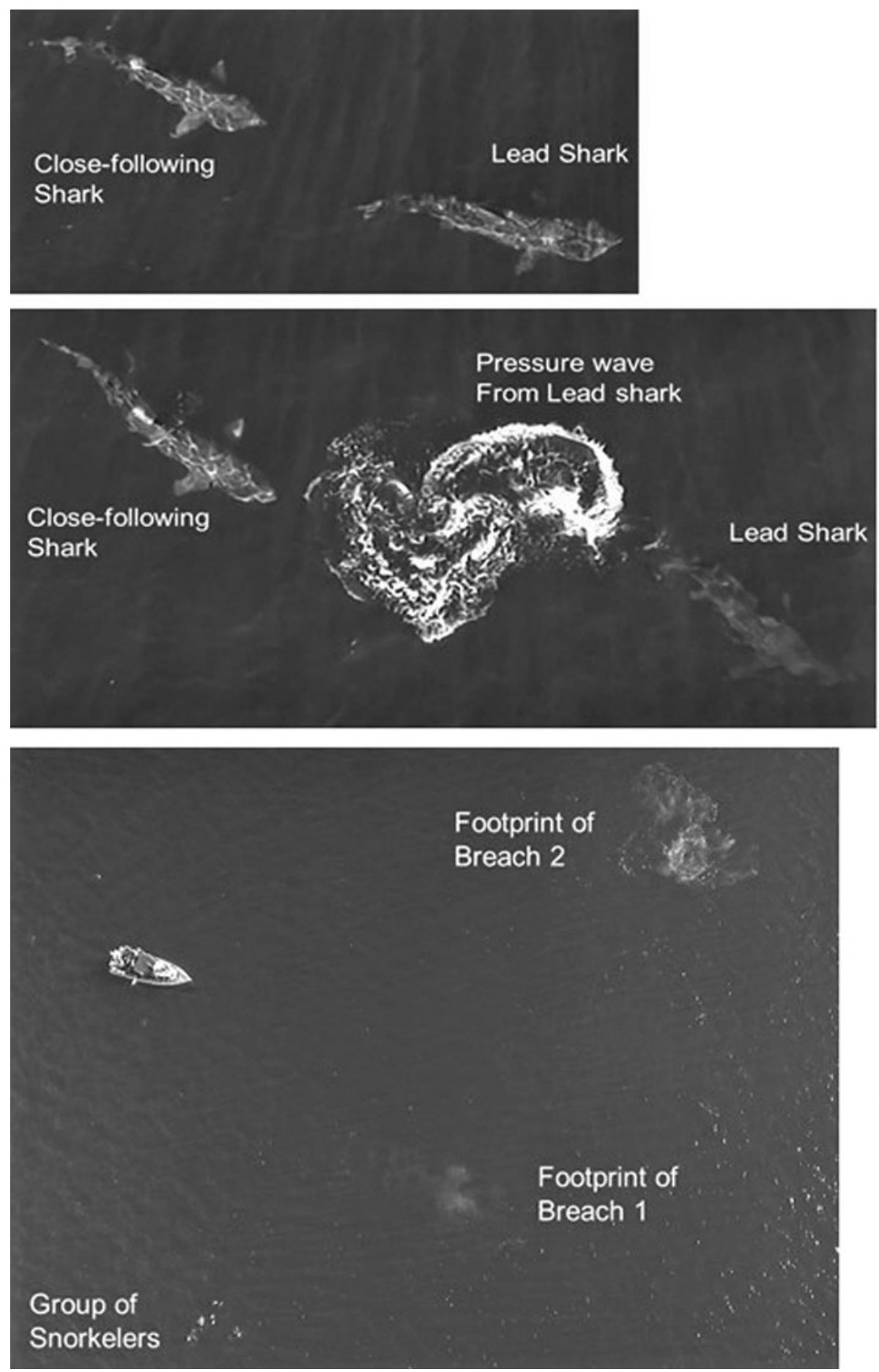

Fig. 8. Sequence of two basking sharks breaching captured by drone. (Top) a $6 \mathrm{~m}$ lead and a $5 \mathrm{~m}$ close-following female, both feeding. (Middle) the lead shark diving and the pressure wave from the dive footprint about to reach the follower's nose. (Bottom) the footprint of the two breaches (solid white arrow) and the position of a group of nearby snorkellers (arrow outline) and the accompanying RIB (inflatable boat) in the top left of the image.

rings, which could be the result of healing of the characteristic near-circular white scars being logged in this study. Abrasions on the nose seem not to be related to the sex of the shark, being evident on almost the same proportions of individuals of each sex $(20.0 \%$ of males and $21.7 \%$ of females). However, abrasions on the pectoral fins were observed in $43.5 \%$ of females but only $10.0 \%$ of males, suggesting that some or most of these abrasions may be a consequence of recent attempted mating out of view of the observers. The only abrasions on gills recorded were on two males.

\section{Breaching behaviour}

While breaching clear of the water has been reported in some shark species (see Introduction), comparable breaching behaviour is more frequently associated with marine 


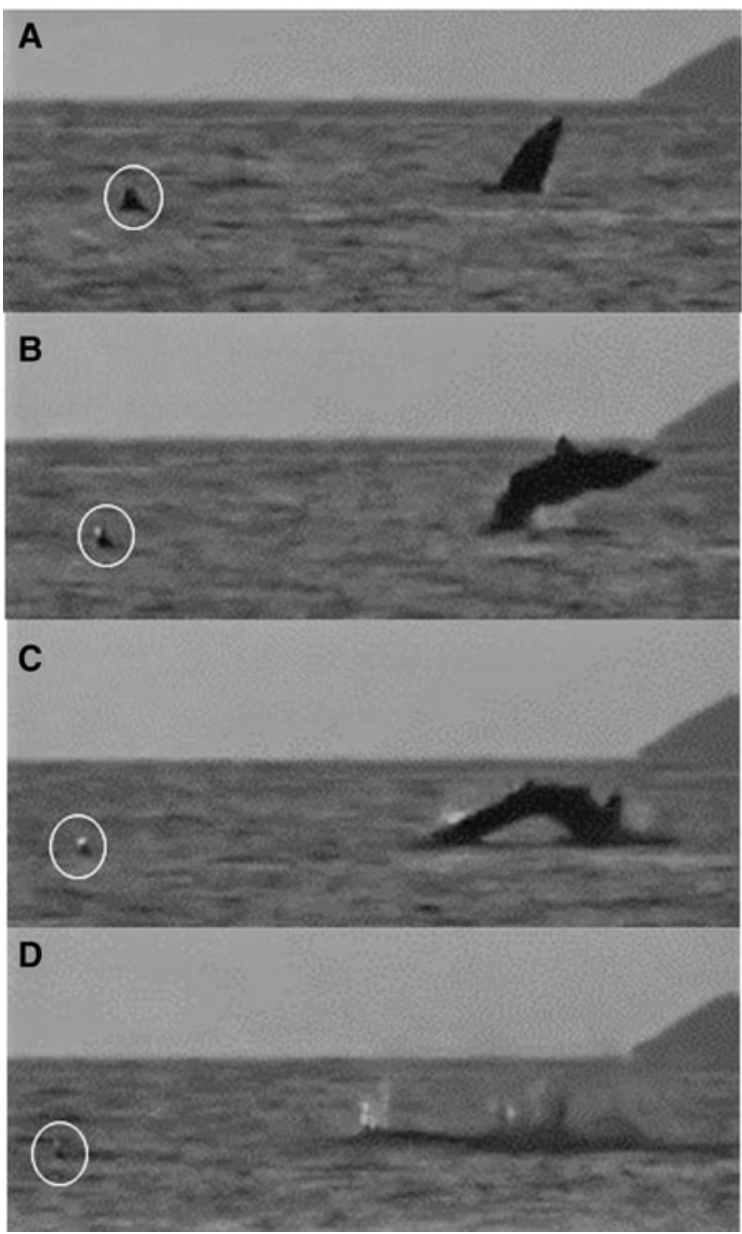

Fig. 9. A basking shark breaching at dusk 21:00 on 22 July 2015 close to and away from a conspecific (circled) (Appendix 1(h)) off the Cairns of Coll, Scotland. Breaching begins at (A) and ends with (D).

mammals, notably some large whale species. The factors prompting breaching in whales are also uncertain, but in humpback whales (Megaptera novaeanglia) these include increased frequency during windy conditions and the presence of multiple calves and of conspecific groups $1-4 \mathrm{~km}$ away (Kavanagh et al., 2016). In sperm whales (Physeter macrocephalus) breaching bouts can last several hours (Waters \& Whitehead, 1990). Aerial behaviour including breaching in humpback whales has been shown to occur prior to a change in behaviour and Frankel et al. (1995) suggest that intentionally or not it may convey information to other whales, such as an animal's location or behavioural state. These authors also commented that aerial behaviour is presumably much more energy consuming than vocalization and so is unlikely to be used exclusively for acoustic signalling.

The observations described here confirm that in contrast to some earlier opinions breaching in basking sharks is not infrequent and suggest that it may have more than one trigger. Breaching was observed to occur both in sharks that appeared to be alone and by others that were in aggregations. Six of the seven occasions involving two to five repeated breaches occurred when the breaching shark was close to one or more conspecifics, while the fact that breaching was only observed on certain days suggested that breaching by one shark may trigger breaching by another (for example, see
Figure 8). The shark launches itself partially or wholly clear of the water, typically landing close by at a near-horizontal angle with a considerable and audible splash (for an example see Appendix 1(g)). The impact on the water on re-entry (APPEA, 2013; Kavanagh et al., 2016) could communicate both its presence and size. Both trends suggest that breaching may have a social function, possibly providing a mechanism by which an individual can draw the attention of others to its presence. Alternatively breaching might possibly be used to deter or escape a potential predator such as an orca (Orcinus orca), small numbers of which occasionally occur in the study area, although none were noted during the present study. Conversely, white sharks breach when hunting their seal prey, but will launch suboptimal strikes in areas of intraspecific competition, leading to a lower predation success (Martin et al., 2005). There is the possibility in the present study that some breaching may have been partly triggered by the shark sensing the presence of snorkellers (Figure 8). However a breaching event outside the present study was observed by MG from close-by (sitting $10 \mathrm{~m}$ above overlooking the cove) without any possible disturbance as follows. An immature $3 \mathrm{~m}$ basking shark swam alone into a small deserted sandy cove and suddenly breached, before unhurriedly swimming back out of the cove again. No other shark was in or near the cove.

Another explanation sometimes advanced is that breaching may serve to rid sharks of parasites or commensals. Jumping out of the water in an apparent attempt to dislodge sharksuckers, Echeneis naucrates, attached to their body has been described for both blacktip and white sharks (Ritter \& Brunnschweiler, 2003; Brunnschweiler, 2006). As noted above, in the present study some basking sharks had lampreys attached to their body. Among the few cases where breaching sharks could be checked for the presence of lampreys, one shark did appear to have a lamprey attached to the first dorsal fin, but this appeared to be still attached as the shark re-entered the water.

Basking shark breaches also occur frequently off Malin Head, Co. Donegal, Ireland, where about 600 have been noted by Bren Whelan (personal communication). Matching our own data, he has observed a very large number of multiple breaches including one occasion when apparently the same shark breached three times within $90 \mathrm{~s}$. He also recorded an occasion when two sharks breached in near unison within $50 \mathrm{~m}$ of each other. Both Whelan's experience and our own records noted that breaching was much more frequent in 2016 than in 2015, and in general seems to be more frequent in some years than others. Whelan has noted that SST at Malin Head varies significantly from year to year and suggests breaching may be more common when the sea is warmer. Along similar lines Schwartz (2013) has suggested that an abrupt change in water temperature may trigger jumping and spinning out of the water in both blacktip and spinner sharks (C. brevipinna).

\section{Is close-swimming related to courtship?}

The sizes of basking sharks recorded during the study showed a normal distribution (Figure 2) with a mean size of $4.96 \mathrm{~m}$. Where individuals could be sexed the size range of males was $3-6 \mathrm{~m}$ and of females $3-7 \mathrm{~m}$. Size at maturity for basking sharks is uncertain. In Scotland basking sharks have been suggested to mature at $>6.22 \mathrm{~m}$ total length $(\mathrm{N}=1)$ 
with a mean of $8.12 \pm 0.16 \mathrm{~m}(\mathrm{~N}=3)$ for males and $7.24 \mathrm{~m}$ $(\mathrm{N}=1)$ with a mean of $8.24 \pm 0.12 \mathrm{~m}(\mathrm{~N}=5)$ for females (Matthews, 1950). By contrast Bigelow \& Schroeder (1948) found in the western North Atlantic that males mature at 4.57-6.10 m. Ali et al. (2012) recorded a $6.9 \mathrm{~m}$ female basking shark off Syria that was pregnant. These results suggest that the larger females and males in the present study could have been mature and so pre-courtship and mating behaviour might be expected.

Nonetheless, no indication was observed throughout the study of a following shark attempting to grab the pectoral fin of the shark it was following. Further, as the leader and follower shark were equally likely to be of either sex, and there was no observed mean difference in size between leader and follower, this suggests that the following behaviour observed is not primarily related to courtship. The difficulty in being sure about the sex of a proportion of individuals might explain occasional records of females apparently following males, even if in fact it is exclusively males that follow females. However it is unlikely that occasional errors of this type could explain the complete lack of any correlation between gender and leader or follower position. Similarly, given that a significant difference was observed between mean size of males and females, a difference between mean size of leader and follower might have been expected if it is normally one sex that follows the other, whereas in fact none was observed.

Swimming patterns of basking sharks in aggregations have been described to include milling, flank approaching from one side, parallel swimming, swimming in echelon formation, following, nose-to-tail following and cart-wheeling (Hallacher, 1977; Sims et al., 2000; Wilson, 2004), although these terms have not always been clearly defined. Sims et al. (2000) described how a leading shark may be followed by up to three sharks within a distance of less than half a body length. We documented these behaviours, although it must be emphasized that intentional swimming by one shark towards another only happened on a minority $25.4 \%$ of occasions when two or more sharks were in proximity (within $100 \mathrm{~m}$ ) of each other; on the greater number of occasions individuals appeared to be feeding independently albeit on the same concentrations of zooplankton.

Reports of mating behaviour in some other shark species have also described close-following, for example of a female blacktip reef shark by a male, with a second male following $5 \mathrm{~m}$ behind the pair (Johnson \& Nelson, 1978). In this case the female swam with a distinct tail-up posture, which however was not observed in basking sharks in the present study. Other features of the behaviour observed in the present study also fail to point to close-swimming behaviour being related primarily to courtship. First, in most cases of close following, both sharks were feeding (83.7\%) and continued to feed despite the presence of the other shark. Secondly, where the sex of both sharks could be determined, there was no tendency for a male shark to be following a female as might have been anticipated on the basis of comparison with observations of mating in other shark species. On occasions where sharks of the opposite sex were involved, in only $12.9 \%$ was the male following the female, while in the other cases it was the female that was following a male. Thirdly, in a majority $(64.5 \%)$ of all cases where we could identify the sex of individuals, the following shark belonged to the same sex as the lead shark. Thus in the cases we observed the sex of both lead and follower sharks appeared to be determined randomly. Close-following has also been reported in non-copulatory situations in bonnethead and grey reef sharks (Bres, 1993).

The species known so far to show behaviour and prey preference most similar to that of basking sharks at aggregation sites are manta rays, Manta birostris and M. alfredi. A series of locations have now been described, notably in Japan (Homma et al., 1999; Yano et al., 1999), the Maldives (Stevens \& Rubin, 2008; Anderson et al., 2011), Mozambique (Marshall \& Bennett, 2010) and Hawai'i (Deakos, 2012), where seasonal aggregations of mantas form to take advantage of dense swarms of zooplankton concentrated by the local topography. Here feeding mantas often show echelon swimming, with sometimes up to 10 or more animals swimming in extended formation, presumably to benefit hydrodynamically from the swimming movements of the individuals forward of them. However pre-copulatory behaviour has also been observed at these sites, with one or more males forming a 'mating train' swimming in fast pursuit of a single female (Yano et al., 1999; Stevens \& Rubin, 2008; Marshall \& Bennett, 2010). The fast swimming is interrupted by quick turns and somersaults initiated by the female and often mimicked by the pursuing males (Marshall \& Bennett, 2010). Mating itself has also on occasion been observed; the leading male, typically after several attempts, bites the female's pectoral fin before twisting to insert a clasper into the female's cloaca (Yano et al., 1999). Thus, in these species, there is clearer circumstantial evidence to indicate that while formation swimming is primarily related to feeding, males also take the opportunity to pursue available females. To date, there are no published records of closefollowing behaviour in the two other plankton-feeding elasmobranchs, whale (Rhincodon typus) and megamouth (Megachasma pelagios) sharks.

\section{Alternative explanations for close swimming}

A number of alternative explanations for close-following and echelon swimming suggest themselves. First, it may provide an energy saving hydrodynamic advantage to the following shark. A basking shark positioned near to the pectoral fin of another may benefit from the echelon formation, as geese and some other large flocking birds are believed to do (Lebar Bajec \& Heppner, 2009), while a shark directly behind another may be in its slipstream. There would be an even greater hydrodynamic advantage by swimming with the mouth closed. Saving energy through swimming in schools is known for other fish, for instance for the golden grey mullet, Liza aurata (Marras et al., 2015). In addition, Reale (2012) designed a 'Strait Power' turbine based on filter feeding in basking sharks. His calculations suggest that the shape of the shark's head is such that as it swims along a pressure differential is created between the mouth and the body below the gills. This draws water passively through the gills, in contrast to the increased pressure required to push water through the gills such as is believed to occur in ram filtering in whale sharks and megamouth sharks (Motta \& Wilga, 2001; Nakaya et al., 2008). It is possible that this same hydrodynamic effect may also benefit an individual feeding alongside or behind another, or it may result in the plankton missed by the first individual being funnelled towards the second within the turbulence created by the leader. 
The behaviour of zooplankton themselves may also benefit an echelon-swimming or close-following basking shark. The copepod Calanus finmarchicus forms an important part of basking shark diet (Blumer et al., 1964; Sims et al., 2005). Fields et al. (2012) studied the escape response of this species and found that later life stages are able to use mechano-sensing to detect pressure changes associated with the approach of a predator. They are also able to make large jumps relative to their body size, involving 400 times their normal energy expenditure, as opposed to the breast stroke movements mainly used while feeding (Wadhwa et al. 2015). This suggests that while some of the calanoid prey immediately ahead of an approaching basking shark may be able to jump out of its way, a second shark may benefit by positioning itself behind and to one side, so that it can catch the copepods after they have jumped. The ability of the copepod to make a second jump is much reduced as a result of the loss of energy reserves after the first jump (Wadhwa et al., 2015), leaving it in the path of a following shark.

Our data suggest that even if on at least some occasions close following and echelon swimming in basking sharks were to lead to mating, it is not the only or primary reason why these sharks may interact with each other. In the great majority of instances they focused strongly on feeding even when close following or echelon swimming, and there are probably one or more mechanisms by which a following shark can gain some energy advantage, either by using less energy or gaining more prey. In our dataset there was no tendency for sharks swimming close to each other to be of opposite sexes and no tendency for either the lead shark or the follower to be of a particular sex. It is also possible that basking sharks, particularly when younger, cannot tell the sex of another individual except by its response to a sexual advance. This is known to be the case in a number of bird species, most famously the European robin (Lack, 1943). It also remains possible, as proposed by Sims et al. (2000) that, while basking sharks aggregate in certain areas primarily in order to feed, it may benefit males to take advantage of the close proximity of other individuals to test whether or not females may be receptive. Such a system is common among herbivorous mammals, such as Uganda kob (Leuthold, 1966), with mature males competing for dominance of the prime areas where females concentrate to feed.

\section{CONCLUDING REMARKS}

The present study has confirmed that basking sharks will, at locations where feeding aggregations tend to form, show following and close-following behaviour. We have been able to provide clear documentation of this behaviour on video sequences captured by an overhead drone. These actions have been interpreted in the literature as courtship or premating behaviour. However, we observed no sign of actual mating and contrary to expectation, we found no relationship between the sex of a shark or its size and close-following. This suggests that following behaviour in these circumstances is not primarily courtship. Further, abrasions on the nose suspected to be related to mating were found to occur on both sexes. Breaching by basking sharks has also been proposed as a means of attracting the opposite sex. We observed breaching to be not infrequent and captured examples of the behaviour on video, but again there was no clear evidence to indicate that breaching is strongly associated with mating. It seems more likely that individuals show close-following primarily for feeding-related hydrodynamic advantage. It remains plausible that mature sharks use feeding aggregations to make initial contact with receptive females. Thus for the time being it seems safest to retain the terminology proposed by Sims et al. (2000) and refer to such behaviour as pre-courtship (rather than courtship) activity. Further research is needed to resolve these issues, ideally at locations where a higher proportion of individuals are mature.

\section{ACKNDWLEDGEMENTS}

We would like to thank Dan Beecham, Bren Whelan and Laurent Cocherel for allowing us to analyse video footage of basking sharks that they had taken and Bren Whelan for very helpful discussions on breaching behaviour. We also thank Anthony Reale for his insight and discussion of modelling basking shark feeding mechanisms. Basking Shark Scotland is a member of the WiSE scheme.

\section{REFERENCES}

Ali M., Saad A., Reynaud C. and Capapé C. (2012) Occurrence of basking shark, Cetorhinus maximus (Elasmobranchii: Lamniformes: Cetorhinidae), off the Syrian coast (eastern Mediterranean) with first description of egg case. Acta Ichthyologica et Piscatoria 42, 335-339.

Anderson R.C., Adam M.S. and Goes J.I. (2011) From monsoons to mantas: seasonal distribution of Manta alfredi in the Maldives. Fisheries Oceanography 20, 104-113.

Australian Petroleum Production \& Exploration Association Limited (2013) Seismic and the marine environment. www.appea.com.au/ wp-content/uploads/2013/05/Seismic_and_the_Marine_Environment. pdf.

Bigelow H.B. and Schroeder W.C. (1948) Fishes of the western North Atlantic, part I: lancelets, cyclostomes, sharks. Memoirs of the Sears Foundation for Marine Research 1, 59-576.

Bloomfield A. and Solandt J.-L. (2008) Basking shark watch 20 year report (1987-2006). Ross-on-Wye: Marine Conservation Society.

Blumer M., Mullin M.M. and Thomas D.W. (1964) Pristane in the marine environment. Helgoländer Wissenschaftliche Meeresuntersuchungen 10, 187-201.

Bres M. (1993) The behaviour of sharks. Reviews in Fish Biology and Fisheries 3, 133-159.

Brunnschweiler J.M. (2006) Sharksucker-shark interaction in two carcharhinid species. Marine Ecology 27, 89-94.

Clarke C.R., Lea J.S.E. and Ormond R.F.G. (2013) Changing relative abundance and behaviour of silky and grey reef sharks baited over 12 years on a Red Sea reef. Marine and Freshwater Research. doi:

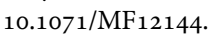

Curtis T.H. and Macesic L.J. (2011) Observations of breaching behaviour in juvenile bull sharks, Carcharhinus leucas. Florida Scientist 74, 253257.

Deakos M.H. (2012) The reproductive ecology of resident manta rays (Manta alfredi) off Maui, Hawaii, with an emphasis on body size. Environmental Biology of Fishes 94, 443-456. 
Demski L.S. (1990) Neuroendocrine mechanisms controlling the sexual development and behaviour of sharks and rays. Journal of Aquariculture and Aquatic Sciences 5, 53-67.

Fields D.M., Shema S.D., Browman H.I., Browne T.Q. and Skiftesvik A.B. (2012) Light primes the escape response of the calanoid copepod, Calanus finmarchicus. PLoS ONE 7, e39594.

Frankel A.S., Clark C.W., Herman L.M. and Gabriele C.M. (1995) Spatial distribution, habitat utilization, and social interactions of humpback whales, Megaptera novaeangliae, off Hawai'i, determined using acoustic and visual techniques. Canadian Journal of Zoology $73,1134-1146$

Gore M.A., Frey P.H., Ormond R.F., Allan H. and Gilkes G. (2016) Use of photo-identification and mark-recapture methodology to assess basking shark (Cetorhinus maximus) populations. PLOS ONE 11. doi: 10.1371/journal.pone.0150160.

Gore M.A., Rowat D., Hall J., Gell F.R. and Ormond R.F. (2008) Transatlantic migration and deep mid-ocean diving by basking shark. Biology Letters 4, 395-398.

Hallacher L.E. (1977) On the feeding behaviour of the basking shark, Cetorhinus maximus. Environmental Biology of Fishes 2, 297-298.

Harvey-Clarke C.J., Stobo W.T., Helle E. and Mattson M. (1999) Putative mating behavior in basking sharks off the Nova Scotia coast. Copeia 1999, 780-782.

Homma K., Maruyama T., Itoh T., Ishihara H. and Uchida S. (1999) Biology of the manta ray, Manta birostris Walbaum, in the Indo-Pacific. In Seret B. and Sire J.-Y. (eds) Proceedings of the fifth international conference on Indo-Pacific fishes, Noumea, 1997. Paris: Societe Francais Ichtyologique, pp. 209-216.

Jacoby D.M.P., Croft D.P. and Sims D.W. (2012) Social behaviour in sharks and rays: analysis, patterns and implications for conservation. Fish and Fisheries 13, 399-417.

Johnson R.H. and Nelson D.R. (1978) Copulation and possible olfactionmediated pair formation in two species of Carcharhinid sharks. Copeia $1978,539-542$

Kavanagh A.S., Owen K., Williamson M.J., Blomberg S.P., Noad M.J., Goldizen A.W., Kniest E. and Cato D.H. (2016) Evidence for the functions of surface-active behaviors in humpback whales (Megaptera novaeangliae). Marine Mammal Science 33, 313-334.

Klimley A.P. (1980) Observations of courtship and copulation in the nurse shark, Ginglymostoma cirratum. Copeia 1980, 878-882.

Lack D. (1943) The life of the robin. London: H.F. and G. Witherby.

Lebar Bajec I. and Heppner F. (2009) Organized flight in birds. Animal Behaviour 78, 777-789.

Leuthold W. (1966) Variations in territorial behavior of Uganda kob Adenota kob thomasi (Neumann 1896). Behaviour 27, 215-257.

Marras S., Killen S.S., Lindström J., McKenzie D.J., Steffensen J.F. and Domenici P. (2015) Fish swimming in schools save energy regardless of their spatial position. Behavioral Ecology and Sociobiology 69, $219-226$.

Marshall A. and Bennett M. (2010) Reproductive ecology of the reef manta ray Manta alfredi in southern Mozambique. Journal of Fish Biology 77, 169-190.

Martin R.A., Hammerschlag N., Collier R.S. and Fallows C. (2005) Predatory behaviour of white sharks (Carcharodon carcharias) at Seal Island, South Africa. Journal of the Marine Biological Association of the United Kingdom 85, 1121-1135.

Matthews L.H. (1950) Reproduction in the basking shark, Cetorhinus maximus (Gunner). Philosophical Transactions of the Royal Society of London Series B, Biological Sciences 234, 247-316.
Motta P.J. and Wilga C.D. (2001) Advances in the study of feeding behaviors, mechanisms, and mechanics of sharks. Environmental Biology of Fishes 60, 131-156.

Myrberg A.A. Jr and Gruber S.H. (1974) The behaviour of the bonnethead shark, Sphyrna tiburo. Copeia 1974, 358-374.

Nakaya K., Matsumoto R. and Suda K. (2008) Feeding strategy of the megamouth shark Megachasma pelagios (Lamniformes: Megachasmidae). Journal of Fish Biology 73, 17-34.

Nicholson D., Harris E. and Pollard S. (2000) The location and usage of sites in Scotland by the basking sharks Cetorhinus maximus. Scottish Natural Heritage Commissioned Report F99AA402.

Pratt H.L. and Carrier J.C. (2001) A review of elasmobranch reproductive behavior with a case study on the nurse shark, Ginglymostoma cirratum. Environmental Biology of Fishes 6o, 157-188.

Reale A. (2012) Toothless shark bites into green energy: Anthony Reale at TEDxDetroit 2012. https://www.youtube.com/watch?v=glBhAhTRyKA.

Ritter E.K. and Brunnschweiler J.M. (2003) Do sharksuckers, Echeneis naucrates, induce jump behaviour in blacktip sharks, Carcharhinus limbatus? Marine and Freshwater Behaviour and Physiology 36, $111-113$.

Schwartz F. (2013) Jumping and spinning by carcharhinid sharks: another view. Journal of the North Carolina Academy of Sciences 129, 107110.

Sims D., Fowler S.L., Clò S., Jung A., Soldo A. and Bariche M. (2015) Cetorhinus maximus. The IUCN Red List of Threatened Species 2015.http://www.iucnredlist.org/details/4292/1.

Sims D.W. (2008) Sieving a living: a review of the biology, ecology and conservation status of the plankton-feeding basking shark Cetorhinus maximus. Advances in Marine Biology 54, 171-220.

Sims D.W., Southall E.J., Quayle V.A. and Fox A.M. (2000) Annual social behaviour of basking sharks associated with coastal front areas. Philosophical Transactions of the Royal Society of London Series B, Biological Sciences 267, 1897-1904.

Sims D.W., Southall E.J., Tarling G.A. and Metcalfe J.D. (2005) Habitat-specific normal and reverse diel vertical migration in the plankton-feeding basking shark. Journal of Animal Ecology 74, $755-761$.

Skomal G.B., Zeeman S.I., Chisholm J.H., Summers E.L., Walsh H.J., McMahon K.W. and Thorrold S.R. (2009) Transequatorial migrations by basking sharks in the Western Atlantic Ocean. Current Biology 19, 1019-1022. doi: 10.1016/j.cub.2009.04.019.

Southall E.J., Sims D.W., Metcalfe J.D., Doyle J.I., Fanshawe S., Lacey C., Shrimpton J., Solandt J.-L. and Speedie C.D. (2005) Spatial distribution patterns of basking sharks on the European shelf: preliminary comparison of satellite-tag geolocation, survey and public sightings data. Journal of the Marine Biological Association of the United Kingdom 85, 1083-1088.

Speedie C.D., Johnson L.A. and Witt M.J. (2009) Basking shark hotspots on the west coast of Scotland: key sites, threats and implications for conservation of the species. Scottish Natural Heritage Commissioned Report No. 339 .

Stevens G. and Rubin R.D. (2008) Reproductive behaviour, mating and male competition in manta rays (Manta birostris). Joint Meeting of Ichthyologists and Herpetologists, Montreal, Canada.

Sund O. (1943) Et Brugdebrasel. Naturen 67, 285-286.

Tricas T.C. and Le Feuvre E.M. (1985) Mating in the reef white-tip shark Triaenodoon obesus. Marine Biology 84, 233-237.

UKHO (2016) Admiralty Easy Tide [Online]. Available at http://www. ukho.gov.uk/easytide/EasyTide/index.aspx. 
Wadhwa N., Andersen A.P., Kiørboe T. and Bohr T. (2015) Zooplankton hydrodynamics: an investigation into the physics of aquatic interactions. Kongens Lyngby: Technical University of Denmark.

Waters S. and Whitehead H. (1990) Aerial behaviour in sperm whales. Canadian Journal of Zoology 68, 2076-2082.

Whitney N.M., Pratt H.L. Jr and Carrier J.C. (2004) Group courtship, mating behaviour and siphon sac function in the whitetip reef shark, Triaenodon obesus. Animal Behaviour 68, 1435-1442.

Wilson S.G. (2004) Basking sharks (Cetorhinus maximus) schooling in the southern Gulf of Maine. Fisheries Oceanography 13, 283-286.

and

Yano K., Sato F. and Takahashi T. (1999) Observations of mating behavior of the manta ray, Manta birostris, at the Ogasawara Islands. Ichthyological Research 46, 289-296.

\section{Correspondence should be addressed to:}

\section{Gore}

Marine Conservation International and Heriot-Watt

University, Edinburgh, Scotland

email: mauvis.gore.mci@gmail.com

\section{APPENDIX1}

List of additional video recordings.

(a) Basking Shark Scotland, Oban, Scotland, UK

(b) Beecham, D. 2007. Sennen Cove.

(c) Carthy, J., Caliso Bay, County Waterford, Ireland. 12.5.2016, https://www.youtube.com/watch? $\mathrm{v}=\mathrm{CsF}_{5} \mathrm{OPM} 3 \mathrm{hDQ}$

(d) Creamer, R., Caliso Bay, County Waterford, Ireland. 13.5.2016, www.youtube.com/watch? $\mathrm{v}=\mathrm{q} 2 \mathrm{VmWgyzlow}$

(e) Ring, E., Youghal Bay, County Cork, Ireland. 6.6.2016, https://www.youtube.com/watch?v=fnHQomD-knE\&t=159

(f) Ring, K., Youghal Bay, County Cork, Ireland. 1.6.2014, https://www.youtube.com/watch? $\mathrm{v}=\mathrm{CsF}_{5} \mathrm{OPM}_{3} \mathrm{hDQ}$

(g) Whelan, B., Malin Head, County Donegal, Ireland. 22.9.2015, https://www.youtube.com/watch?v=ojwX_gb_CHQ

(h) Cocherel, L. Gunna Sound, Scotland, https://vimeo.com/ 135502913 